ILLÉSSY MIKLÓS - CSIZMADIA PÉTER ${ }^{1}$

A TÁRSADALMI INTEGRÁCIÓ INTÉZMÉNYI KÖRNYEZETE:

A JÓLÉTI ÁLLAMOK SOKFÉLESÉGÉNEK ELMÉLETI MEGKÖZELÍTÉSEI

\title{
Dol: 10.18030/socio.hu.2015.3.105
}

\section{ABSZTRAKT}

A magyarországi integrációs és dezintegrációs folyamatok megértése lehetetlen a posztszocialista átalakulás intézményi változásainak elemzése nélkül. Jelen tanulmányban arra teszünk kísérletet, hogy felvázoljuk ezen intézményi változások interpretálásának egy lehetséges elméleti keretét. Ehhez a „kapitalizmus sokfélesége" nemzetközi szakirodalmát hívtuk segítségül, illetve ezen belül azokat a munkákat tekintettük át részletesebben, amelyek a közép-kelet-európai térség országaiban, így Magyarországon végbemenő folyamatok elemzésével foglalkoznak. A szakirodalom áttekintése során elsősorban azokkal a munkákkal foglalkoztunk, amelyek a munkaerő-piac, az oktatás és a szociális ellátórendszer integratív funkcióját vizsgálták. A térség elmúlt negyedszázadának koherens magyarázóerővel bíró interpretálása máig adóssága a társadalomtudománynak, így erre mi sem vállalkozhattunk. Ehelyett igyekeztünk olyan kérdéseket megfogalmazni, amelyek megválaszolása közelebb vihet a probléma megértéséhez és elemzéséhez.

Kulcsszavak: társadalmi integráció, jóléti állam, posztszocialista átalakulás, munkaerő-piac

\section{INSTITUTIONAL FRAMEWORK OF SOCIAL INTEGRATION:}

THEORETICAL APPROACHES OF VARIETIES OF WELFARE STATES

\section{ABSTRACT}

It is impossible to understand the processes of integration and disintegration in the Hungarian society without analysing institutional changes of the post-socialist transformation as a whole. In the present study, our aim is to sketch a theoretical framework suitable to interpret these institutional changes. By doing so, we largely rely on the 'Varieties of Capitalism' literature, and within this theoretical stream, special focus was given to studies analysing integrative and disintegrative mechanisms in Central Eastern Europe, and in Hungary. We also put special emphasis on the analyses aimed to better understand the labour market, educational and welfare system and their role in social integration during the transformation process. So far, social sciences proved to be unable to give coherent interpretation of this transformation, and we can't compensate for this shortage either. Instead, we tried to formulate questions the answer to which may help to understand and analyse the processes of integration and disintegration in the Hungarian society.

Keywords: social integration, welfare state, post-socialist transformation, labour market

1 MTA Társadalomtudományi Kutatóközpont Szociológiai Intézet 


\section{ILLÉSSY MIKLÓS - CSIZMADIA PÉTER}

\section{A TÁRSADALMI INTEGRÁCIÓ INTÉZMÉNYI KÖRNYEZETE: A JÓLÉTI ÁLLAMOK SOKFÉLESÉGÉNEK ELMÉLETI MEGKÖZELÍTÉSEI²}

A társadalom integrációs és dezintegrációs folyamatait alapvetően befolyásolja az adott társadalom intézményeinek sikeres vagy éppen diszfunkcionális múködése. Alábbi írásunkban ${ }^{3}$ arra teszünk kísérletet, hogy bemutassuk az európai jóléti államok változatos intézményi berendezkedéseivel kapcsolatos elméleti megközelítéseket. Elsőként röviden áttekintjük az intézmények fogalmával kapcsolatos megközelítéseket és a különböző intézményi berendezkedések összehasonlító vizsgálatával összefüggő elméleti alapokat. Ezt követően bemutatjuk a jóléti államok és/vagy a tőkés gazdaságok különböző intézményi típusainak azonosítására irányuló kísérleteket, különös tekintettel azon kisszámú tanulmányra, amelyek a magyar intézményi berendezkedés sajátosságaival (is) foglalkoznak, végül igyekszünk az intézményi környezet és a társadalmi integráció összefüggéséivel kapcsolatos elméleti és empirikus kihívásokat áttekinteni. Jelen írás célja az MTA TK Szociológiai Intézetében zajló Integrációs és dezintegrációs folyamatok a magyar társadalomban című OTKA kutatás keretében zajló empirikus kutatási program intézményekkel kapcsolatos részterületének elméleti megalapozása.

Az intézmények társadalomban betöltött szerepének kérdésköre szinte a kezdetektől jelen volt a szociológiában és a közgazdaságtanban, és az elmúlt néhány évtizedben újra az érdeklődés középpontjába került. A megnövekedett figyelem ellenére az „intézmény” fogalma meglehetősen inkoherens módon jelenik meg a társadalomtudományokban. Az elméleti megközelítésekben két jól azonosítható irányzat létezik. Az egyik a jogtudomány, a politikatudomány és a szervezetszociológia gondolatköréből táplálkozik, és hajlamos az intézményeket a formális intézményekkel és/vagy szervezetekkel azonosítani. (Ebben az értelemben beszél például az Európai Unió intézményeiről.) A másik megközelítés a közgazdaságtani, antropológiai és szociológiai hagyományokra támaszkodva, az intézmények alatt a társadalmi szereplők viselkedését és egymással való társas interakcióikat befolyásoló normákat, értékeket, formális és informális szabályokat érti (Hage 2000, North 1990, Soskice 2000). Ez utóbbi megközelítésen belül is érdemes különbséget tenni aszerint, hogy az intézményeket az emberi interakciók eredményének, vagy ellenkezőleg, a cselekvők mozgásterét behatároló, rajtuk kívül létező entitásoknak írják le, esetleg a fenti dichotómia meghaladására törekszenek (Bourdieu 1990, Giddens 1984).

Az intézményekkel foglalkozó kutatások egyik legsokrétúbb, ugyanakkor a legtöbb módszertani nehézséget jelentő területe az intézményi környezetek nemzetközi összehasonlítása, amely többek között olyan kérdésekre keresi a választ, hogy milyen intézményi konstellációk befolyásolják a különböző országok vagy régiók eltérő teljesítményeit, vagy hogy milyen hasonlóságok és különbségek vannak az intézmények múködésében az egyes országokban, illetve, hogy az egyes intézményi gyakorlatok hogyan terjednek el a világban és eközben milyen módosulásokon mennek keresztül.

2 A szerzők köszönetet mondanak Simonyi Ágnesnek a tanulmányhoz füzött értékes megjegyzéseiért.

3 A tanulmány elkészítését az OTKA 108836 sz. Integráció és dezintegráció a magyar társadalomban c. kutatás támogatta. 
A nemzetközi összehasonlító kutatások problematikájának módszertani és elméleti nehézségeivel kapcsolatban érdemes Marc Maurice francia szociológus tipológiájára hagyatkozni (Maurice 2000). A szerző háromféle nemzetközi összehasonlításokat végző iskolát különböztet meg, két fontosabb szempont alapján. Az egyik szempont az elemzés szintje, vagyis hogy mikro-, mezo- vagy makroszinten vizsgálunk-e egy adott jelenséget. A másik szempont a folytonosságot jelenti, pontosabban, hogy az elemzés képes-e a valamiféle történetiség, trend jelzésére, vagy ezzel a problémával nem foglalkozik. E két szempontrendszer alapján lehetővé válik annak vizsgálata, hogy egy adott jelenség mennyire tekinthető endogénnek, vagyis mennyire illeszkedik egy adott kontextusba, illetve mennyire heterogén vagy homogén, ami az adott jelenség egyediségére utal. A fentiek alapján Maurice három jellegzetes megközelítést különböztet meg, amelyek a következők:

a. funkcionalista iskola (cross-national),

b. kultúralista megközelítés (cross-cultural),

c. „társadalmi hatás” megközelítés (inter-national).

A funkcionalista megközelítésben az összehasonlíthatóság a racionalitás elvén nyugszik, amely egyfajta kontinuitást feltételez, vagyis hogy az egyes jelenségek országról országra mutatónként összehasonlíthatók (pl. a munkanélküliségi ráta összehasonlítása anélkül, hogy bármit is megtudnánk az egyes országok munkaügyi kapcsolatainak vagy foglalkoztatási rendszerének speciális karakteréről). A funkcionalista iskola ezért az egyes országok közötti esetleges különbségekkel nem foglalkozik érdemben, azokat vagy az általa felállított modell elhanyagolható elemeként kezeli, vagy funkcionális azonosságként. Ebben a megközelítésben az egyes társadalmi jelenségek nemzeti kontextusa nem képezi vizsgálat tárgyát, ebben az értelemben a funkcionalista megközelítés univerzalisztikus és kultúra-független (culture-free).

A kultúralista megközelítés az egyes pontban vázolt szempontok mindegyikében éles ellentéte a funkcionalista megközelítésnek. E megközelítésben a nemzeti kontextus maga a vizsgálat tárgya, hiszen a nemzeti kultúra olyan erős befolyással bír az egyes jelenségek országonként különböző változataira, hogy lehetetlen ezeket országról országra automatikusan összehasonlítani. Míg tehát a funkcionalista megközelítés egyfajta folytonosságot feltételez a vizsgált jelenségekben az egyes országok között, a kultúralista megközelítés tagadja ezt (diszkontinuitás), ami következésképpen gyengíti ezen elméletek általános magyarázó erejét. Az összehasonlíthatóság - már amennyiben létezik - csak egymástól különböző kulturális univerzumok között jöhet létre, míg a funkcionalista megközelítés egyetlen - folytonos, tehát problémamentesen összehasonlítható - univerzumot feltételez. Mindkét megközelítésben közös, hogy a nemzeti kontextusok (vagy a nemzeti kultúrák) és a vizsgált jelenségek közötti kapcsolatot nem elemzik.

A Maurice által harmadikként leírt megközelítés az úgynevezett „társadalmi hatás” iskola. Ez a megközelítés nem az egyes jelenségeket próbálja meg elemenként automatikusan összehasonlítani, ehelyett az egymásra kölcsönösen ható jelenségek együttese által formált nemzeti „koherenciákat” vizsgálja, amelyek országonként eltérőek. A megközelítés alapelve nem a „racionalitás”, sem pedig a „nemzeti kultúra”, sokkal inkább a társadalmi aktorok azonosítása társadalmi kapcsolataikkal együtt. Ebben az értelemben a társadalmi hatás iskola a strukturalista elemzések egy speciális formája, amely nem zárja ki a társadalmi szereplőket a vizsgálatból, hanem éppen ellenkezőleg, azokat a struktúráktól elválaszthatatlan elemként kezeli (a struktúrák, intézmények és 
az aktorok kölcsönösen hatnak egymásra). A társadalmi hatás megközelítésben egyszerre van jelen a különböző országok közötti diszkontinuitás (amely kizárja a leegyszerűsített összehasonlítás lehetőségét) és kontinuitás, amennyiben az egyedi társadalmi konstellációk - szerkezetükben és a maguk teljességében - összehasonlíthatók. E megközelítés tehát egyszerre igyekszik meghaladni a funkcionalista és a kultúralista iskola korábbiakban vázolt korlátait, mindezt azonban nem a két paradigma valamilyen integrálásával, sokkal inkább az elemzés logikájának áthelyezésével. Míg a funkcionalista megközelítés a vizsgált társadalmi jelenségek de-szocializációjára törekszik (legalábbis ez következik a nemzeti kontextusok fontosságának relativizálásából), a társadalmi hatás iskola egyik célja éppen e társadalmi karakter számbavétele, az országok közötti leegyszerúsített és éppen a de-szocializációból következő kontinuitás tagadása. Ezzel szemben a kultúralista megközelítés az egyes társadalmak egyediségét hangsúlyozza, ennyiben tehát ez az iskola szintén az egyes országok között diszkontinuitás elvét vallja. A legfontosabb különbség a kultúralista és a társadalmi megközelítés között abban rejlik, hogy előbbi ugyan a nemzeti kultúra egyediségére hivatkozva utasítja el az országok közötti összehasonlítás lehetőségét, anélkül azonban, hogy e „nemzeti kultúrát” igazán vizsgálat tárgyává tenné, a rá történő folytonos hivatkozás mellett is egyfajta „fekete dobozként” kezeli.

\section{A JÓLÉTI ÁLLAM/TŐKÉS GAZDASÁG MODELLEI ${ }^{4}$}

Az intézmények összehasonlító vizsgálatának többsége - többnyire implicit módon - a társadalmi hatás megközelítést képviseli, az intézményeket magukat pedig a társadalmi cselekvők mozgásterét meghatározó vagy legalábbis erősen befolyásoló tényezőknek tekintik. A különböző országok eltérő társadalmi-gazdasági modelljeiről szóló szisztematikus elméletek az 1990-es évek elején kerültek a figyelem középpontjába (EspingAndersen 1990, Albert 1991). ${ }^{5}$ Ezek két nagyobb csoportra oszthatók: dichotóm, illetve többdimenziós modellekre. Előbbiek közé tartozik Albert (1991) elmélete, aki szerint Európa olyan politikai entitás, amely a maga speciális intézményeivel nem redukálható pusztán egy szabadkereskedelmi övezetre vagy éppen az eurózónára. Albert ennek alapján két egymástól alapvetően különböző kapitalizmus-modellt különböztet meg, a rajnait és az angolszászt. Elóbbire Európában jó példa Németország vagy Ausztria, Ázsiában pedig Japán, az angolszász modelleket pedig az Atlanti-óceán két partján az USA, Nagy-Britannia, illetve Írország testesíti meg leginkább. Bár Albert szerint az országok sajátos intézményi berendezkedése miatt nem beszélhetünk egyetlen európai modellről, számos vonatkozásban a rajnai modellt fejlettebbnek tartja az angolszásznál. Ennek oka, hogy szerinte a rajnai modell általános értelemben jobban illeszkedik az európai társadalmak igényeihez. Ebből adódóan Albert nem osztja azt a véleményt sem, mely szerint az angolszász modell győztesen kerülne ki a különböző kapitalizmus-típusok közötti szabad versenyből. Szerinte az európai integráció politikai folyamata is a rajnai modell elterjesztéséről, legfontosabb elemeinek általánossá tételéről szól a tagországok között.

4 Ez a fejezet a Makó-Csizmadia-Illéssy 2013 vonatkozó részének átdolgozott és kibővített változata.

5 A jóléti állam első elemzései már az 1950-es évek végén megjelentek (Titmuss 1958), az összehasonlító politikai gazdaságtan pedig a 70-es években elkezdett foglalkozni a témával, majd a 80-as években folytatódott az elsősorban a skandináv jóléti államok gazdaságtanával kapcsolatos komparatív diskurzus (Lindbeck 1975, Cameron 1978, Katzenstein 1985). A jóléti államok sokféleségének tematikájához kapcsolódik az intézményi konvergencia és divergencia problémája, amely már a 60-as évektől jelen van a politikai gazdaságtan diskurzusában (Shonfield 1960, Zysman 1983, Hall 1986, Thelen-Steinmo 1992). A gondolati előzmények között feltétlenül érdemes még megemlíteni a francia „regulációs iskolát”, amely a munkaerő-piacok, a szervezeti koordináció és a tudásfelhasználás együttes vizsgálatával végzett elemzéseket a gazdasági átalakulás problémájáról (Boyer 1990). 
A dichotóm elméletek közül a legnagyobb hatású kétségkívül Hall és Soskice munkája (2001). Elméletük, melynek neve a kapitalizmus sokfélesége („Varieties of Capitalism - VoC”), központi szereplője a vállalat, amely állandóan azon dolgozik, hogy a dinamikus alkalmazkodáshoz szükséges képességeit fejlessze annak érdekében, hogy a tevékenységeivel összefüggő koordinációs problémákat minél magasabb szinten tudja megoldani. E koordináció mikéntjében pedig meghatározó szerepe van annak az intézményi berendezkedésnek, amely az adott ország által képviselt kapitalizmusváltozatra jellemző. Hall és Soskice különösen az alábbi intézmények fontosságára hívják fel a figyelmet a vállalati koordinációs mechanizmusok kialakításában:

1. a munkaügyi kapcsolatok rendszere (pl. az egyéni vagy kollektív koordinációs mechanizmusok a foglalkoztatási és munkafeltételekről a munkavállalók vagy érdekképviseleti szervezeteik bevonásával);

2. a vállalatirányítás (beleértve a tulajdonviszonyokat, melyek alapvetően határozzák meg a vállalaton belüli projektek finanszírozását);

3. a szakképzés és oktatás rendszere (a vállalati és ágazati képzési rendszerek és ezek illeszkedése, kiterjedtsége, a képzés fontossága);

4. a vállalatközi kapcsolatok (pl. a kooperáció vagy versengés-e a jellemzőbb a cégek közötti kapcsolatokra, a formális vagy informális hálózatokban való részvétel szerepe és fontossága);

5. a vállalaton belüli kapcsolatok (pl. milyen módszerekkel és szervezeti megoldásokkal ösztönzik a munkavállalókat, hogy nem kódolt vagy tacit tudásukat megosszák egymással, milyen formális vagy informális kommunikációs csatornákat működtetnek a munkavállalók és a vállalati vezetés között (Hall-Soskice 2001:9).

A fent röviden ismertetett öt intézmény alapján Hall és Soskice (2001) kidolgozták a kapitalizmus különböző modelljeinek bináris klasszifikációját, melyben a két alaptípus a liberális piacgazdaság (liberal market economies - LME) és a koordinált piacgazdaság (coordinated market economies - CME). A két modell közötti legnagyobb különbséget az adott gazdaságban uralkodó főbb koordinációs mechanizmusok jelentik.

A piacgazdaság liberális modelljében a vállalatok közötti koordináció alapvetően a piaci mechanizmusokon történik, ahol felértékelődik a könnyen transzferálható eszközökbe történő befektetések szerepe. A koordinált piacgazdasági modellben ezzel szemben a vállalatközi koordináció alapvetően nem piaci mechanizmusok útján valósul meg és dominálnak a speciális eszközökben történő befektetések. A gazdasági és társadalmi koordináció fenti különbségei Amable (2005:15) szerint a következő különbségeket eredményezik: „A liberális piacgazdaságokat (...) a rövid távon megtérülő befektetések, a deregulált munkaerő-piac, az általános képzést nyújtó oktatási formák, valamint erős piaci verseny jellemzi. A koordinált piacgazdaságokra pedig a hosszú távon megtérülő befektetések, a kooperatív munkaügyi kapcsolatok, fejlett szakképzési rendszer, gyengébb piaci verseny és a szakmai szervezetek közötti erős, többé vagy kevésbé formális információcsere jellemző, melynek célja a közös iparági standardok felállítása. Ezek a különbségek túlmutatnak az innováció vagy a technológiai változások aktuális állapotán és nem vezethetők vissza az egyes nemzetgazdaságok ágazati különbségeire sem, amelyek az úgynevezett komparatív intézményi előnyök forrásai." 
Mint minden bináris megkülönböztetés kapcsán, a piacgazdaság liberális és koordinált változataira épülő tipizálás esetében is jelentős probléma, hogy ha minden országot e két alaptípus valamelyikébe szeretnénk besorolni, akkor fontos nemzeti sajátosságokat hagyhatunk figyelmen kívül, melynek eredményeként az egész klasszifikáció értelmét veszítené. Ezért tehát érdemes úgy gondolni az LME és a CME kategóriáira, mint ugyanannak a skálának a két szélső értékére. A legtöbb ország pedig e két szélső ideáltípus között helyezkedik el. Annak érdekében, hogy pontosabb képet kapjunk a bináris tipológia gyengéiről, röviden érdemes számba venni az alternatív magyarázatokat is, amelyek több-kevesebb sikerrel igyekeztek meghaladni azt.

\section{A KAPITALIZMUS SOKFÉLESÉGÉNEK TÖBBDIMENZIÓS MEGKÖZELÍTÉSEI}

Több szerző is megpróbálta meghaladni a fent említett problémákat, például Esping-Andersen (1990), Boyer (1996), Amable (2005), Sapir (2005), Composto (2008), Martin (2008), Greskovits (2010). E szerzők az intézményi sajátosságokat vizsgálva igyekeztek olyan együttállásokat, egymást kiegészítő elemeket azonosítani, amelyek segítségével egy több típust tartalmazó kapitalizmus-tipológia is felállítható. A fenti szerzők közül megítélésünk szerint Amable (2005, 1997) és Sapir (2005) különösen alkalmasak lehetnek arra, hogy jobban megértsük az intézményi sajátságok egymásra épülő olyan kölcsönhatásait, mint amilyenek például a felsőoktatás teljesítménye és a különböző jóléti modellek között találhatók.

Amable és Sapir is túllépett a dichotóm megközelítésen, és az európai szociális modellek négy, illetve öt típusát különböztették meg. Mielőtt részletesen ismertetnénk ezeket, meg kell jegyeznünk, hogy sajnálatos módon egyik szerző sem foglalkozott a közép-kelet-európai tagállamokkal. E tíz tagországot az irodalom általában külön kategóriaként tartja számon, bár az erősen kérdéses, hogy ezek valóban annyira homogének-e, esetleg közöttük legalább akkora differenciák tapasztalhatók, mint az Európai Unió 15 régi tagállama között. Sapir (2005) az európai szociális modellek általa azonosított négy modelljének a teljesítményét igyekezett öszszehasonlítani a méltányosság és a hatékonyság dimenziói szerint. Kiindulópontja szerint az olyan fogalmak, mint az „európai szociális modell”, a „szociális Európa”, vagy az „Európai modell” félrevezetőek: „(...) valójában ilyen dolgok nem léteznek. Európa számos szociális modellnek ad otthont, amelyek számos tulajdonságukban különböznek, így a hatékonyság és a méltányosság dimenziói szerint nyújtott teljesítményükben is." Az általa felállított koordinátarendszerben egy modellről akkor állítható, hogy hatékony, ha az kellőképpen ösztönzi a munkavállalást, vagyis magas foglalkoztatási rátákat produkál. Méltányosnak pedig akkor nevezhető egy adott modell, ha képes viszonylag alacsony szinten tartani a szegénység kockázatát. ${ }^{6}$

Sapir tehát a hatékonyság és a méltányosság dimenzióiban nyújtott szociálpolitikai teljesítményük alapján négy csoportba osztotta az európai országokat. Az északi országok között találjuk Dániát, Finnországot, Svédországot és Hollandiát. Erre az országcsoportra jellemző, hogy esetükben a legmagasabbak a szociális kiadások, jóléti rendszerükre az univerzális ellátások a jellemzők. Az állam jelentős szereplő a munkaerő-piacon, jelentős mennyiségű pénzt költ az aktív munkaerő-piaci eszközök széles tárházára. Ezen felül a szakszervezetek is erősek, fejlett a társadalmi párbeszéd kultúrája, ami magas bérszínvonalat és az egyes jövedelmi csoportok

$6 \mathrm{ltt}$ kell felhívnunk a figyelmet arra, hogy mind a foglalkoztatás, mind pedig az anyagi jólétből való részesedés mértéke fontos tényezői a társadalmi integrációnak. Ez azt is jelenti, hogy a mindkét dimenzióban jól teljesítő országok egyúttal a társadalmi integráció magasabb fokát is képviselik. 
közötti különbségek alacsony relatív szintjét eredményezi.

Az angolszász országok közé az Egyesült Királyság és Î́rország tartozik. Rájuk a legszegényebbek bőkezú szociális segélyezése jellemző. E pénzbeli juttatások leginkább az aktív korú népességet célozzák, a segélyekhez való hozzáférést így gyakran állandó foglalkoztatáshoz kötik. Munkaerő-piacukra a gyenge szakszervezetek, a relative nagy és egyre növekvő bérkülönbségek és a dolgozó szegények magas aránya jellemző.

A kontinentális országok közé Sapir Ausztriát, Belgiumot, Franciaországot, Németországot és Luxemburgot sorolja. Ennek a rendszernek a legfontosabb megkülönböztető sajátossága a biztosítási alapú járadékok, valamint az öregkori nyugdíj kiemelt szerepe. Habár a szakszervezetek taglétszáma egyre csökken, azok még mindig viszonylag erősek, a kollektív megállapodásokat jellemzően kiterjesztik a nem szervezett munkahelyekre és munkavállalókra is.

A mediterrán országcsoportban Görögország, Olaszország, Portugália és Spanyolország kapott helyet. Szociális kiadásaikban az öregségi nyugdíjak jelentik a legnagyobb tételt, a jogosultságok és státuszok nagyfokú szegmentáltsága jellemző. A jóléti juttatások legnagyobb része foglalkoztatáshoz kötött, az aktív korúak jelentős részét kedvezményes nyugdíjazással mentesítik munkaerő-piaci kötelezettségeik alól. A bérstruktúra, legalábbis a gazdaság törvényes szegmenseiben, a kollektív megállapodásoknak köszönhetően nyomott, alacsony szintú egyenlőtlenség jellemzi.

Amint azt Sapir is megjegyzi, a közgazdászok által kedvelt tipológia Esping-Andersen (1990) korábbi politikai szociológiai munkáján alapul, amely eredetileg három alaptípust különböztetett meg: a liberális rezsimet (amely az angolszász csoportnak feleltethető meg), a konzervatív rezsimet (amely a kontinentális és a mediterrán országcsoport tagjait foglalja magában) és a szociáldemokrata rezsimet (amely az északi országcsoportot tömöríti). Az 1. táblázat a Sapir által kidolgozott tipológiát jeleníti meg.

\section{1. táblázat. Az európai szociális modellek négyes tipológiája}

\begin{tabular}{|l|l|l|l|}
\hline \multirow{4}{*}{ Méltányosság } & & Hatékonyság \\
\cline { 2 - 4 } & & Alacsony & Magas \\
\cline { 2 - 4 } & Magas & „Kontinentális” (AT, BE, DE, FR, LU) & "Északi” (DK, FI, NL, SE) \\
\cline { 2 - 4 } & Alacsony & „Mediterrán” (ES, GR, IT, PT) & "Angolszász” (IE, UK) \\
\hline
\end{tabular}

Forrás: Sapir (2005:9), idézi Makó-Csizmadia-Illéssy 2013: 7.

A fenti táblázatnak legalább kétféle értelmezése lehetséges. Az első a hatékonyság és a méltányosság közötti trade-off-ról szól. Az északi és a mediterrán országcsoport esetében semmilyen átváltásról nem beszélhetünk. Amint azt Sapir is megjegyzi: „Az északi országcsoport irigylésre méltó helyzetben van, hiszen a társadalmi berendezkedés egyszerre hatékony és méltányos. Ezzel szemben a mediterrán országok társadalmi berendezkedése sem a méltányosság, sem a hatékonyság kritériumainak nem felel meg. Az angolszász és a kontinentális országok esetében egyfajta átváltásról beszélhetünk a hatékonyság és a méltányosság között. Az angolszász országoknak hatékony, de nem méltányos szociális modellel rendelkeznek, míg a kontinentális országoké méltányosabb, de jóval kevésbé hatékony." (Sapir 2005:15) 
A táblázat másik értelmezési lehetősége az egyes modellek fenntarthatóságáról szól. Azok a modellek, amelyek nem képesek adekvát válaszokat adni a csökkenő állami kiadások, a globalizáció következtében felerősödő verseny, valamint a gyors technológiai és szervezeti innovációk támasztotta kihívásokra, nem fenntarthatók. Sapir szerint a kevésbé hatékony kontinentális és mediterrán modellek jelentős fenntarthatósági problémákkal küzdenek. Ennek egyik jele szerinte, hogy az államadósság GDP-hez viszonyított aránya a kontinentális országcsoportban 73\%, a mediterránban pedig 81\%, míg az angolszász és északi országok esetében ez az arány jelentősen kisebb (sorrendben 36, illetve 49\%). A globalizáció társadalmi megítélésében szintén nagy mértékú különbségek mutatkoznak. Az angolszász és az északi országokban ugyanis jóval kedvezőbben ítélik meg a globalizációt, mint a kontinentális és a mediterrán országokban. A Eurobarometer felmérés adatai szerint, mondja Sapir, a kontinentális országokban a megkérdezettek 52\%-a, a mediterrán országokban a megkérdezettek 45\%-a válaszolt úgy, hogy a globalizáció fenyegetést jelent vagy negatívan befolyásolhatja a foglalkoztatást, míg az angolszász és északi országokban ugyanez az arány 36, illetve 37\%.

A méltányosság és a hatékonyság közötti átváltás azonban nem eredményez egyformán fenntartható modelleket, hiszen csak a hatékony szociális modellek fenntarthatók: „(...) Az északi és az angolszász országok fenntarthatók, ezzel szemben a kontinentális és a mediterrán modellek nem. Ezekben az országokban jelentős reformlépésekre lesz szükség a hatékonyság növelésének érdekében, valamint azért, hogy jobban ösztönözzenek a munkavállalásra és a növekedésre. Másfelől semmi okunk a priori feltételezni, hogy ezeknek a változásoknak a méltányosság dimenzióit is érinteniük kellene. Könnyen elképzelhető, hogy a kontinentális modellek az északi modellek irányába mozdulnak el, míg a mediterrán országcsoportra jellemző modell az angolszászhoz válik hasonlóvá. Mindazonáltal nem lehet kizárni annak lehetőségét, hogy a nagyobb hatékonyság irányába tett reformok az eredetinél több vagy méltányosságot eredményeznek, ha a hatékonyság növelésének érdekében történt változások a korábbi politikai egyensúlyt is felborítják." (Sapir, 200:10)7 Ezzel kapcsolatban azonban némi szkepticizmusra ad okot az a fejlemény, hogy az utóbbi időben szerte Európában a munkaerő-piaci deregulációnak lehetünk szemtanúi.

A kapitalizmus sokféleségének másik, tanulmányunkban ismertetendő többdimenziós tipológiáját Bruno Amable dolgozta ki. (Amable, 2005) Amable munkája során az innováció és a termelés társadalmi rendszereinek elméleti áramlatából indult ki. Modelljébe ezért a következő területek empirikus adatait integrálta: tudomány és technológia, gazdasági szerkezet, oktatási rendszer és munkaerő-piac. Tipológiája nagyban hasonlít Sapir modelljére, de Amable kiegészítette azt az „ázsiai kapitalizmus” modelljével, így nála a kapitalizmusnak öt ideáltipikus modellje létezik:

1. piaci alapú gazdaságok, liberális piacgazdaságok avagy az angolszász modell,

2. szociáldemokrata gazdaságok,

3. ázsiai kapitalizmus,

4. kontinentális európai kapitalizmus,

5. dél-európai kapitalizmus.

A liberális piacgazdaság modelljében a termékek és szolgáltatások piacán megnyilvánuló intenzív ver-

7 Hangsúlyoznunk kell, hogy Sapir elemzése a 2007-ben elindult globális pénzpiaci és reálgazdasági válság előtt készült. A válság rávilágított, hogy az egyes modellek fenntarthatóságáról szóló elképzelések legalábbis vitathatók. 
seny arra készteti a vállalatokat, hogy kínálatukban gyorsan reagáljanak a változó igényekhez. Amint Amable (2005:19) megjegyzi: „Ha az árak csökkentésével nem lehet lenyelni a kereslet visszaesését, akkor a mennyiséget is csökkenteni kell, különösen a munkaerőben. A termékpiaci verseny így vezet a foglalkoztatás de facto rugalmasságához."

Ezzel szemben a szociáldemokrata modell a versenyképességet nem a rugalmasság numerikus vagy munkaerő-piaci eszközeivel, hanem a magasan kvalifikált munkaerő átképzésével és továbbképzésével érik el. „A munkavállalók speciális invesztícióinak védelmét foglalkoztatás biztonságának közepes szintjével érik el, mely fejlett színvonalú szociális védelemmel párosul, valamint a képzésekhez történő széleskörú hozzáféréssel az aktív munkaerő-piaci politikáknak köszönhetően." (Amable, 2005:20)

A kapitalizmus ázsiai modellje duális gazdaságon alapul, melyet a szociális háló hiánya és a fejlett pénzügyi szektor jellemez. Ebben a rendszerben a nagyvállalatoknak kitüntetett szerep jut, amelyek az élethosszig tartó foglalkoztatáson és a magas béreken keresztül garantálják a társadalmi szolidaritást. Ezzel szemben a kis és közepes méretú vállalkozások sem a foglalkoztatás biztonságát, sem pedig a magas béreket nem tudják biztosítani. A kapitalizmus ezen modelljének sikere: „(...) a nagyvállalatok üzleti stratégiáján, az állam közremúködésén és a központosított pénzügyi rendszeren múlik, amelyek lehetővé teszik a hosszú távú tervezést." (Amable, 2005:20)

Az úgynevezett kontinentális európai modell számos ponton hasonlít az előbb röviden jellemzett szociáldemokrata modellhez. A munkaerő átképzése azonban korántsem olyan széles körben elterjedt, mint a szociáldemokrata modell esetében, ami erős korlátot jelent a munkavállalók rugalmassága és az iparágak válságok utáni gyors helyreállításának szempontjából. (Amable, 2005)

A mediterrán modellre az erős foglalkoztatási védelem, a gyenge piaci verseny és a rövid távú pénzügyi kényszerek hiánya jellemző. Ezzel egy időben ugyanakkor a munkaerő képzetlensége és alacsony oktatási szintje gátat szab a nagy szakértelmet magas bérekkel honoráló gazdaságfejlesztési stratégiának. (Amable, 2005) Az úgynevezett „low-skill equilibrium”-tól a „high-skill equilibrium” felé történő elmozdulást célzó stratégiák megvalósítása annál is inkább nehéznek túnik, mivel egyszerre kívánja meg a társadalmi partnerek hosszú távú, elkötelezett együttmúködését és a munkaadók, munkavállalók, politikai döntéshozók gondolkodásmódjának radikális átalakítását.

A különböző szociális modellek Sapir vagy Amable által kidolgozott osztályozási kísérletének kapcsán ki kell emelnünk azt a tényt, hogy a valóságban egyik ország sem felel meg 100\%-os pontossággal a felállított négy vagy öt típus követelményeinek, ezek inkább stilizált modelleknek vagy ideáltípusoknak tekinthetők.

Összegezve az eddig elmondottakat megállapítható, hogy Sapir és Amable koncepciójában nem csak az a különbség, hogy a kapitalizmus modelljének Sapir négy, míg Amable öt alaptípusát különbözteti meg. Sapir elmélete ugyanis lehetőséget nyújt arra, hogy a méltányosság és a hatékonyság dimenzióin keresztül egyszerre mérje a modellek szociális és gazdasági teljesítményét. Amable ezzel szemben nagyobb hangsúlyt helyez az egyes intézményi berendezkedések elemei között meglévő kapcsolatok, a kölcsönös egymásra hatások természetének vizsgálatára. 


\section{A TERMELÉSI RENDSZEREKRE KONCENTRÁLÓ MEGKÖZELÍTÉSEKEN TÚL: \\ A FOGLALKOZTATÁSI REZSIMEK ELMÉLETE}

A kapitalizmus sokfélesége elméleteket részben meghaladni, részben továbbfejleszteni kívánó Duncan Gallie (2007) munkájának ismertetésével zárjuk e rövid áttekintő részt. Gallie-t elsősorban az egyes intézményi berendezkedések munkaminőségre gyakorolt hatása foglalkoztatta. A kapitalista társadalmak teljesítménybeli különbségeit vizsgálva Gallie a vonatkozó szakirodalom két nagyobb ágát különbözteti meg. Az első a korporatista elméleti hagyományban gyökerező termelési rezsimek elmélete, köztük a kapitalizmus sokfélesége megközelítés, mely annyiban szakított elődeivel, hogy az elemzés középpontjában nem makroszintű folyamatok és mutatók álltak, hanem a vállalati teljesítmény és a vállalatok közötti koordináció típusai.

Mint azt korábban részletesen is bemutattuk, a kapitalizmus sokféleségének elmélete azt vizsgálja, hogy a vállalatok jellemzően milyen koordinációs mechanizmusokkal igyekeznek megoldani a múködésük során felmerülő problémákat, illetve hogy ezen mechanizmusokat hogyan és milyen mértékben határozzák meg egy adott ország intézményi berendezkedésének speciális elemei, mint a munkaügyi kapcsolatok, az oktatás és szakképzés rendszere, a vállalatirányítás domináns formái, valamint a vállalaton belüli és vállalatok közötti kapcsolatok. Ennek alapján az elmélet megkülönbözteti a piacgazdaság liberális és koordinált modelljeit. Az előbbiben a koordináció jellemzően a hierarchikus viszonyokon és a piaci alapú viszonyokon keresztül valósul meg, míg utóbbi esetben a koordináció nem piaci formái az uralkodóak. Az elóbbire jó példát jelentenek az angolszász országok: az Egyesült Királyság és Î́rország, az utóbbira Németország és a skandináv országok. Hall és Soskice a piacgazdaság koordinált modelljein belül beszélt annak altípusairól, mint a centralizált és nagy mértékben egalitáriánus északi modellről, a rugalmas koordinációjáról ismert Németországról és Ausztriáról, valamint a mediterrán országokról. (Hall-Soskice 2001)

A foglalkoztatási rezsim elmélete abban különbözik a termelési rezsim elméleteitől, hogy a termelés helyett az erőforrások elosztásáról kötött alkukra koncentrál, ilyen értelemben tehát közelebb áll az esping-andersen-i jóléti állam-tipológiához, amelynek elméleti kiindulópontja az, hogy a jóléti állam kialakulása a 20. században a munkaadók, a szakszervezet és az állam között létrejött kompromisszumok eredményének tekinthető. A foglalkoztatás és a munkaügyi kapcsolatok rendszerének összefüggéseit elemezve Gallie a foglalkoztatási rezsimek három típusát különböztette meg: az inkluzív (befogadó), a duális és a piaci modelleket. A befogadó rezsimekre jellemző, hogy olyan foglalkoztatáspolitika kialakítására törekszenek, amely a foglalkoztatás és a munkavállalói jogokat egyszerre szeretné olyan szélesen kiterjeszteni, amennyire az csak lehetséges. A duális foglalkoztatási rezsim a kulcs-munkaerő számára erős munkavállalói jogokat garantál, azonban a periférián ragadt munkavállalói rétegek számára sem ezen jogok, sem pedig a munkavállalás biztonsága nem garantált. A piaci foglalkoztatási rezsim minimális mértékben avatkozik be a munkaerő-piac múködésébe, alacsony szintű a munkaügyi szabályozás, a piaci viszonyok magas szintű foglalkoztatottsághoz vezetnek. (Gallie 2007, Lauder et al. 2012)

Kissé leegyszerűsítve tehát azt mondhatjuk, hogy a termelési rezsim elméletei a modern kapitalizmusban az erőforrások előállításának módját befolyásoló intézményi tényezők közötti kölcsönös kapcsolatokat elemzik, míg a foglalkoztatási rezsim elméletei a jóléti állam intézményi sajátosságainak (társadalmi párbeszéd, szociálpolitika, állami beavatkozás mértéke és területei) az erőforrások újraelosztásának módját meghatározó tényezőire koncentrálnak. 


\section{KAPITALIZMUSOK A POSZTSZOCIALISTA TÉRSÉG ORSZÁGAIBAN}

A témával kapcsolatban az elmúlt 25 év talán legátfogóbb munkája Dorothy Bohle és Greskovits Béla Capitalist diversity on Europe's periphery címü könyve, amely arra vállalkozott, hogy számot adjon a rendszerváltozás óta eltelt időszak gazdasági és társadalmi változásairól, illetve e változások nyomán a kelet-európai térségben kialakuló kapitalizmusmodellekről. (Bohle-Greskovits 2012) A szerzők tizenegy kelet-közép-európai állam (Bulgária, Csehország, Észtország, Horvátország, Lengyelország, Lettország, Litvánia, Magyarország, Románia, Szlovákia, Szlovénia) elmúlt negyedszázadban bejárt útját elemzik. A szerzőpáros a kelet-európai kapitalizmusok sokféleségének elemzése kapcsán több módszertani nehézségre hívja fel a figyelmet. A teljesség igénye nélkül ezek közül a következőket érdemes hangsúlyozni. Az egyik, hogy az eredeti kapitalizmustipológiát kifejezetten a nagy országok sajátosságainak modellezésére dolgozták ki, másfelől a posztszocialista átalakulás időben egybeesett olyan generikus változásokkal, mint a globalizáció. Ennek következtében a már létező elméletek nem tudnak mit kezdeni azokról az új intézményekkel, amelyek az átalakulás termékei. A szerzők a térség átalakulásának megértéshez Polányit hívják segítségül: a kapitalizmus két nagy intézményrendszer, az önszabályozó piacok és a szociális védelmet biztosítani hivatott intézmények konfliktusának eredője. A két rendszer konfliktusából megszülető politikai intézményrendszer kapcsán arra a paradoxonra hívják fel a figyelmet, hogy a szocialista rendszer összeomlása után a demokratikus politikai és a piaci alapú gazdasági rendszert egyszerre nem lehetett végrehajtani, mivel a demokratikus rendet csak bizonyos gazdasági kompromisszumok árán lehetett fenntartani, így a posztszocialista országokban kialakult kapitalizmus-modellek a neoliberalizmus, a jóléti állam és a demokratikus korporativizmus sajátos ötvözeteként írhatók le. A szerzők a kapitalizmus három tiszta típusát különböztetik meg a régióban: a balti államokra a neoliberális rezsim, a visegrádi országcsoportra az úgynevezett beágyazott neoliberális rezsim, míg Szlovéniára a neokorporatista rezsim a jellemző. Bulgária és Románia az elmúlt két évtizedben számos szempontból ellenmondásos helyzetben volt, és mindhárom modell jellegzetességeit felmutatja bizonyos mértékig. Bohle és Greskovits egyik legfontosabb mondanivalója, hogy a különböző modellek eltérő mértékben bizonyultak sikeresnek az átalakulás egyes szakaszaiban. Így például az Európai Unióhoz történő csatlakozás a balti államokat érintette a legkedvezőbben, amelyek amúgy is neoliberális rezsimet építettek, amivel a csatlakozási követelmények a leginkább kompatibilisek voltak. A csatlakozás szintén kedvezően hatott Romániára és Bulgáriára is, mert jelentős mértékben javította ezen államok reformkapacitását. A visegrádi országcsoportra ezzel szemben nem gyakorolt látványos hatást, mivel ezek már túl voltak a reformok többségén, miközben a csatlakozás utáni (makroökonómiai és fiskális) stabilitási kényszerek ezen országok kormányainak mozgásterét szúkítették a leginkább.

A kapitalizmus sokféleségének vizsgálata azért is fontos Kelet-Európa olyan országaiban, mint amilyen Magyarország is, mert mintegy 20 éve tart a vita arról, hogy a térségben a szocializmus örökségére építve a jóléti állam milyen modellje vagy modelljei jönnek létre. Az államszocializmus évei alatt kialakult a jóléti államnak a térség országaira jellemző változata, amely a politika, a gazdaság és az újraelosztás társadalmi intézményei között létrejött kényes egyensúly eredménye volt. A nyolcvanas évek végén meginduló és a kilencvenes években kiteljesedő változások megbontották ezt az egyensúlyt. A régi és új szereplőknek újfajta intézményi kötelékeket és koherenciákat kellett kialakítani. 
Hely hiányában a szocializmus örökségének elemzésére itt és most nem vállalkozhatunk, de Szelényi és Wilk egy közelmúltbeli cikkben tesz kísérletet arra, hogy a poszt-kommunista rezsimek intézményi átalakulását az első húsz év tapasztalatainak fényében interpretálja (Szelényi-Wilk, 2010).

A szerzők szerint az átmenet első éveiben a térség országai a piaci viszonyok megteremtésére koncentráltak, a szociális intézményeket lényegében érintetlenül hagyták. Aztán a 90-es évek közepére nyilvánvalóvá vált, hogy a társadalom nem hagyhatja magukra az átalakulás veszteseit. Szelényiék szerint a posztszocialista átalakulás három nagyobb szakaszra osztható: az elsőben a gazdaság reorganizációja valósult meg, amelyet az állam és a politikai folyamatok mélyreható változása kísért egyfelól, másrészt viszont javarészt érintetlenül hagyta a nagy elosztórendszerek múködési mechanizmusait. A jóléti rendszer reformjának igénye az átalakulás második szakaszában merült fel, amikor a neoliberális elvek szerint újjászerveződő gazdaság és a továbbra is a szocialista rendszer örökségeként funkcionáló jóléti rendszerek közötti feszültség egyre kevésbé volt fenntartható. Szelényi és Wilk szerint a gazdaság modernizációja az átalakulás első évtizedében jóval sikeresebb volt, mint a szociális rendszerek ezt követő évtizedben megcélzott átalakítása.

Ennek egyik oka, hogy bár a második világháborút követően a szocialista országok konvergenciája volt megfigyelhető, hiszen a szovjet blokk országai nagyon eltérő gazdasági fejlettségbeli, intézményi és kulturális szinten kezdtek bele a szocialista kísérletbe, az évtizedek alatt ezek a különbségek, ha el nem is tûntek, de jelentős mértékben csökkentek. A politikai, gazdasági és társadalmi átalakulás kezdetével ez a konvergencia-folyamat megszakadt, a közös múlt és a jövő kihívásainak hasonlóságai ellenére ezen országok „eltérő mértékben bizonyultak elkötelezettnek és sikeresnek a kapitalista gazdaság, a demokratikus intézmények és a szociális intézmények megreformálása terén." (Szelényi-Wilk, 2010: 566)

Némileg leegyszerűsítve a szerzők két csoportra osztják a térség államait: a közép-európai országok klasztere Csehországot, Szlovákiát, Lengyelországot, a balti államokat, Magyarországot és az egykori Jugoszlávia két nyugati fekvésű egykori tagállamát, Szlovéniát és Horvátországot foglalja magában. A poszt-szovjet térség másik nagy csoportját a kelet-európai államok alkotják, amelybe az egykori Szovjetunió baltiakon kívüli egykori tagállamai, a Szlovénián és Horvátországon kívüli délszláv ex-államok, Albánia, Bulgária és Románia alkot. Szelényiék szerint utóbbiakra a neo-patrimoniális politikai és gazdasági rendszer jellemző, amelynek fő ismérve a klientalizmus, vagyis a közjavak és állami erőforrások felhasználása a klientúra lojalitásának biztosítása érdekében. Ez a típusú állam legtisztább formájában a putyini Oroszországban figyelhető meg. Ezzel szemben a közép-európai országok a neoliberális modellt követték az átalakulás során. A kettő között nyilvánvaló különbségek találhatók: kuponos privatizáció, az átalakulás lassú folyamata az egyik, sokkterápia és a külföldi tőke meghatározó szerepe a privatizációban a másik oldalon. Szelényiék szerint a közép-európai országok olyan mértékben építették le a „szabad piac” múködésének útjában álló akadályokat, hogy a kilencvenes évtizedben a térség államai neoliberálisabbak voltak, mint az Egyesült Királyság Thatcher vagy az Egyesült Államok Reagan alatt.

Ha összehasonlítjuk a két rendszer teljesítményét, érdekes aszinkronitás figyelhető meg. A kilencvenes évtizedben egyértelműen a neoliberális rendszermodellt követő országok, köztük is az elsők között Magyarország, voltak a legsikeresebb államok, amelyek a kezdeti jelentős visszaesés után viszonylag gyorsan tudtak 
növekedési pályára állni. Ezzel szemben a neopatrimoniális államok a 90-es években igen gyengén teljesítettek: bár a munkanélküliségi rátát általában sikerült viszonylag alacsony tartani, a hiperinfláció és a reformok elmaradása miatt a szegénység gyors ütemben nőtt. Jól jelzi a különbséget, hogy a közép-európai országcsoportban a népesség 2-15\% közötti hányada élt a szegénységi küszöb alatt, míg ugyanez az arány a neopatrimoniális modellt követő Kelet-Európában 25-40\% között mozgott az ezredforduló környékén.

Ennél is érdekesebb, hogy ez a trend a millennium környékén élesen megfordult. Ennek egyik oka, hogy az Európai Unió felé igyekvő országok, Románia és Bulgária jelentős mértékben liberalizálták gazdaságukat, és politikai rendszerük is egyre közelebb került a liberális demokratikus modellhez. A gazdasági nyitás eredményeként a kétezres évek első évtizedében nem egyszer fordult elő, hogy e két állam a korábban sikertörténetnek számító Csehországot, Magyarországot vagy Lengyelországot is messze meghaladó mértékben volt képes külföldi tőkebefektetéseket vonzani az országba. A neopatrimoniális modell sikerének másik tényezője az alapanyagok áremelkedésére alapozott orosz gazdasági csoda volt, amely az ezredfordulót követően éveken keresztül 7-10\%-os gazdasági növekedésre volt képes. Ezzel szemben a már említett három közép-európai gazdasági recessziót tapasztalt meg ebben az évtizedben. A visszaesés időben eltolódva és mértékét tekintve is jelentős különbséggel jelentkezett. Csehországot már 1997-ben elérte a válság első szele, és a növekedés egészen 2004-ig nem is igazán tudott felpörögni. Lengyelország 2001-2002 környékén érte el a mélypontot, viszont Csehországhoz hasonlóan 2004 és 2008 között példátlanul jól teljesítettek, még ha az államadósság mértékén nem is sikerült jelentősen faragni. A legrosszabb helyzetbe Magyarország került, amely 2002 óta nem volt képes növekedésre, a 2008-as gazdasági és pénzügyi válság pedig különösen érzékenyen érintette.

Ami az úgynevezett nagy elosztórendszerek reformját illeti, Szelényi és Wilk szerint ezek megújítása inkább a szolgáltatókat érintette, míg a fogyasztókat jóval kisebb mértékben. Ezen változások közül a legfontosabbak a nyugdíj- és egészségügyi ellátórendszerek leválasztása volt a központi költségvetésről, a magán szolgáltatók megjelenésének engedélyezése a nyugdíjbiztosítás, az egészségügyi ellátás, valamint a felsőoktatás területén. Ez utóbbi területen az egyetemek jelentős mértékű autonómiára tettek szert. A szociálpolitikában a legfontosabb általános trend a szociális ellátások jelentős részének rászorultsági elven nyújtott folyósítása volt. Ezzel együtt a szociális kiadások GDP-hez viszonyított aránya a legtöbb országban a kilencvenes években nagy mértékben emelkedett, ami az átalakulások szociális költségeinek következtében részben elkerülhetetlen is volt. Mindebből e szolgáltatások fogyasztói, leszámítva persze a szociális ellátások területét, szinte semmit nem vettek észre.

A posztszocialista átalakulás második szakaszában, vagyis az ezredfordulót követően az ellátórendszereket illetően is figyelemre méltó dinamikákkal találkozhatunk. Szelényi és Wilk szerint a második évezred első évtizedében a neopatrimoniális modellt követő országok, köztük leginkább Oroszország, radikális neoliberális reformokat hajtottak végre a nagy ellátórendszereikben, míg Közép-Európa neoliberális országaiban szinte minden ilyen kísérlet kudarcba fulladt. A szerzők e kudarc okát elsősorban abban látják, hogy Putyin Oroszországával szemben a közép-európai államok többé-kevésbé jól működő demokráciát múködtettek, ahol a választók négyévente dönthettek a folytatásról. Ez a politikai verseny pedig gátat szabott minden intézményi reformtörekvésnek. Egy másik lehetséges magyarázat szerint a közép-európai országokban a szocializmus évei alatt is múködtek a jóléti rendszer elemei. Természetesen szó sem volt piaci értelemben vett hatékonyságról, 
de többé-kevésbé mindenki megkapta azt, amire számíthatott az egészségügyi, a nyugdíj- vagy a felsőoktatási rendszertől. Kelet-Európa országaiban ezzel szemben sosem múködtek ezek az intézmények, vagyis amikor az átalakulás következtében a szegénység sosem látott méretekben került felszínre, a piaci alapon működő intézmények bevezetésének nem is igazán létezett alternatívája.

Szelényiék legfontosabb állítása tehát, hogy a közép-európai országokban hosszú távon fenntarthatatlan ellentmondás feszül: míg a gazdaságot túlságosan is a neoliberális receptek szerint alakították át, addig a nagy elosztórendszerek többsége továbbra is jórészt a szocialista rendszerből örökölt modell szerint múködik. ${ }^{8}$ Míg tehát a gazdasági szférában túl sok, a jóléti rendszerben túl kevés a neoliberalizmus. Akár így van, akár nem, az intézményi átalakulás folyamata és az új intézményi konfiguráció társadalmi integrációra gyakorolt hatása alaposabb vizsgálatot érdemel, különösen a Közép- és Kelet-európai térség országaiban, így Magyarországon is.

Az elmúlt 25 év mérlegét megvonva érdemes hangsúlyozni, hogy az egykori szocialista országoknak nem sikerült az egykor remélt felzárkózás a nyugat-európai államok jövedelemi szintjére; az eltelt időszak pusztán arra volt elegendő, hogy - néhány fejlett régió kivételével - a térség országai elérjék, vagy némileg meghaladják az 1980-as évek végi teljesítményüket. Szelényi és Wilk megközelítésénél kevésbé ideologikus és empirikusan megalapozottabb Beblavý dolgozata (Beblavý 2008), amely éppen arra hívja fel a figyelmet, hogy az európai integráció és a globalizáció a közös intézményi örökség ellenére is a posztszocialista országok közötti divergenciát eredményezett. Beblavý ennek megfelelően arra a kérdésre keresi a választ, hogy a jóléti állam posztszocialista régióban kialakult változata eltér-e a nyugati országokban azonosított modellektól, illetve ezen belül léteznek-e eltérések az egyes posztszocialista országok között. Elemzésében a következő változókat vette figyelembe:

- a jóléti kiadások mértéke,

- a jóléti kiadások szegénységre gyakorolt hatása,

- a fenti két változó összefüggése,

- a kiegészítő privát nyugdíjbiztosítás mértéke.

Az elemzésben szerepeltek a fenti változók kombinációinak változatosságát magyarázó további tényezők is:

- az átmenettel járó gazdasági sokk mértéke,

- etnikai heterogenitás, különös tekintettel a marginalizált csoportokra,

- a szociális transzferek nélkül mért szegénység mértéke.

Beblavý legfontosabb következtetései a következők. Az egyik, hogy a posztszocialista jóléti államok különböznek a régi tagállamokban kialakult jóléti államoktól, és nem illeszthetők be közvetlenül azokba a modellekbe, amelyek az utóbbiak leírására és klasszifikálására születtek. A 2010-ben csatlakozott országokban a jóléti állam a kiadások volumenét és hatását tekintve kisebb, mint a nyugati országokban, ugyanakkor - és ez egybecseng a korábban idézett Szelényi-Wilk tanulmány megállapításaival -, azoknál jóval nagyobb mértékben támaszkodik a jövedelmek redisztribúciójára a szegénység elleni küzdelemben. Ez utóbbit nevezi a szerző abszolút redisztribúciónak. Megkülönbözteti ugyanakkor a relatív redisztribúció fogalmát is, amely a szociális transzferek szegénységre gyakorolt hatását a jóléti kiadások arányában méri, tehát indirekt módon tükrözi azt 
is, hogy a szociális juttatások elosztása hogyan valósul meg az egyes társadalmi csoportok között. A szerző által használt 2005-ös adatok alapján ebben a tekintetben jelentős különbségek vannak a posztszocialista országok között. A fenti változók segítségével a szerző az alábbi módon tipologizálta régióban múködő jóléti államokat.

2. táblázat. A posztszocialista országokban kialakult jóléti államok típusai

\begin{tabular}{|c|c|c|c|c|c|c|}
\hline \multirow[b]{2}{*}{ Típus } & \multirow[b]{2}{*}{ Országok } & \multicolumn{3}{|c|}{ A jóléti állam dimenziói } & \multicolumn{2}{|c|}{$\begin{array}{c}\text { A jóléti állam méretét és } \\
\text { hatékonyságát befolyásoló } \\
\text { tényezők }\end{array}$} \\
\hline & & $\begin{array}{l}\text { A jóléti } \\
\text { kiadások } \\
\text { mértéke }\end{array}$ & $\begin{array}{l}\text { Abszolút } \\
\text { redisztribúciós } \\
\text { erőfeszítések }\end{array}$ & $\begin{array}{l}\text { Relatív } \\
\text { redisztribúciós } \\
\text { erőfeszítések }\end{array}$ & $\begin{array}{l}\text { Gazdasági } \\
\text { sokk }\end{array}$ & $\begin{array}{c}\text { Etnikai } \\
\text { heterogenitás }\end{array}$ \\
\hline Láthatatlan & Lettország & $A$ & $A$ & $A$ & M & M \\
\hline $\begin{array}{l}\text { Enyhén } \\
\text { liberális }\end{array}$ & $\begin{array}{l}\text { Észtország, } \\
\text { Litvánia }\end{array}$ & A & $A$ & M & M & M \\
\hline $\begin{array}{l}\text { Bizonytalan } \\
\text { közép }\end{array}$ & $\begin{array}{l}\text { Bulgária, Romá- } \\
\text { nia, Szlovákia }\end{array}$ & K & K & M & K & $\mathrm{A} / \mathrm{K}$ \\
\hline $\begin{array}{l}\text { Enyhén } \\
\text { konzervatív }\end{array}$ & $\begin{array}{l}\text { Csehország, } \\
\text { Lengyelország, } \\
\text { Magyarország }\end{array}$ & M & M & K & A & $\mathrm{A} / 0$ \\
\hline $\begin{array}{l}\text { Konzervatív- } \\
\text { közeli }\end{array}$ & Szlovénia & M & M & $A$ & A & 0 \\
\hline
\end{tabular}

$A$ = alacsony mértékü, $K=$ közepes mértékü, $M=$ magas mértékü

Forrás: Beblavý 2008: 17

A Beblavý által használt tipológia az Esping-Andersen által kidolgozott jóléti államtípusokat (szociáldemokrata, liberális és konzervativ) használja összehasonlítási alapként. A „láthatatlan” modell Lettországot jelenti, amely esetében a jóléti állam volumene kicsi, és csekély a redisztribúció szegénységre gyakorolt hatása. Észtország és Litvánia képviseli az enyhén liberális („liberal light”) modellt, amelyek esetében a jóléti állam hasonló logikát követve múködik, mint a liberálisként aposztrofált, tehát a piacelvű megoldásokban és a rászorultsági elvben gondolkodó nyugati országokban, méretében azonban jóval kisebb. Csehország, Lengyelország és Magyarország kerültek az enyhén konzervatív („conservative light”) csoportba, amely az Esping-Andersen-féle konzervatív, azaz a minimális redisztribúciós hatás révén a státuszkülönbségeket konzerváló jóléti állam keleteurópai változata. Szlovénia kilóg ebből a csoportból, mert bár azonos logikára épülnek a jóléti transzferek, de volumenükben nagyobbak, mint a visegrádi országokban, ezért ez a gyakorlat közelebb áll a nyugat-európai értelemben vett konzervatív jóléti modellhez. Bulgária, Románia és Szlovákia a liberális és a konzervatív modell szempontjából köztes helyzetben vannak.

A 2005-ös adatok csak keresztmetszeti képet adnak, az azóta eltelt időszak - különös tekintettel a 2007/8-ban indult pénzügyi és reálgazdasági válságra - bizonyosan hozott változásokat az országok helyzetében. Azt is érdemes hangsúlyozni, hogy a fenti tipológia természetesen vitatható, egy dologra azonban felhívja a figyelmet. Szemben Szelényiék értelmezésével, úgy tűnik, hogy az államszocializmus több szempontból is a teljes foglalkoztatáson és az egyenlősítésen alapuló szociáldemokrata modellhez hasonló (bár attól a transzferek volumenét tekintve jelentősen elmaradó) jóléti gyakorlatát liberális vagy konzervatív logikát képviselő megoldások váltották fel a régióban. A modellváltás ténye tehát jól azonosítható, de arra nézve viszonylag 
kevés koherens magyarázat-kísérlet történt, hogy miért így és miért éppen így ment/megy végbe a folyamat. Ehhez mindenképpen érdemes lenne az intézményi átalakulást a történeti kontextusban vizsgálni, kitágítva az átalakulás vizsgálatának időbeli perspektiváit. Egy ilyenfajta megközelítés arra is lehetőséget teremthetne, hogy azonosíthatóvá váljanak a régió országaiban tartósan, politikai és társadalmi rendszereken átívelő intézményi minták történeti mozgásai, illetve ezek változásának dinamikája.

A fenti gondolatmenethez kapcsolódik a Nemzetközi Munkaügyi Szervezet (International Labour Organization, ILO) egy egészen friss nemzetközi összehasonlító kutatása, amely a 2008-ban kezdődő világgazdasági válság komplex jellegére és a válság hatásainak kezelésére az európai országokban született intézményi válaszok sokféléségére reflektál. (Vaughan-Whitehead, 2015) A kutatók a válság két, egymástól elkülönülő periódusát azonosították. Az első szakasz, amely nagyjából 2009-ig tartott, a közvetlen sokk időszaka, melyet gazdasági visszaesés és a vele járó szociális problémák felerősödése jellemez, elsősorban a foglalkoztatásban. A szociális ellátórendszerek minden európai országban reagáltak a válság hatásaira, aminek következtében az ellátottak száma és ezzel együtt a szociális kiadások mértéke mindenhol drasztikusan nő. A szociális védelem intézményei így kettős feladatot látnak el: egyrészt közvetlenül enyhítik a válság okozta társadalmi sokkhatást, másrészt a kiadások növelésével sikerül stabilizálni a belső lakossági fogyasztást, amely közvetve a további gazdasági károkat enyhíti, illetve előzi meg. A válság kezelésének második szakasza 2010-től kezdődik, ekkortól a szerzők szerint radikális fordulat áll be, elsősorban a jelentős államadóssággal küzdő déli és európai államok válságkezelési gyakorlatában. Ekkortól kezdve elsősorban Európa perifériás régióban megszorítások sora követi egymást, amely jelentősen erodálja a szociális intézményrendszer majdnem mindegyik elemét, kezdve a munkakörülmények romlásától a munkaerő-piacok befogadó jellegének és a társadalmi párbeszéd csatornáinak beszúkülésén át a szociális, jóléti szolgáltatások színvonalában és a hozzáférés lehetőségeiben bekövetkező kedvezőtlen változásokig. A megszorítások jelentősen gyengítették a válság első szakaszában jól teljesítő, a válság hatásait legalább részben ellensúlyozni és annak társadalmi költségeit csökkenteni képes szociális ellátórendszert, miközben a remélt gazdasági felzárkózás elmaradt. Mindeközben azokban az országokban, amelyekben a válság és annak kezelése érintetlenül hagyta a társadalmi párbeszéd jól kialakult csatornáit, sikerült olyan kompromisszumokra jutni, amelyek a válság körülményei között is életképes alternatívát kínáltak a társadalmi szereplők számára. (A szerzők elsősorban Németország, Ausztria és Franciaország példájára hivatkoznak.) A periféria országai ezzel szemben elkezdték megvágni a szociális kiadásokat és leépíteni szociális ellátórendszereiket, aminek következtében tartósan magas munkanélküliség alakult ki, radikálisan nőtt a szegénységben élők száma, és megrendült a középosztály helyzete. Mindez egy lefelé tartó spirált eredményezett: miközben a megszorítások negatív következményei azonnal jelentkeztek, a fogyasztóképes kereslet csökkenése és a beruházások elmaradása miatt a gazdasági helyzet sem tudott javulni.

A megszorítások logikája arra az elképzelésre vezethető vissza, amely a szociális intézményeket és ellátórendszert nem a gazdasági fejlődés alapvető társadalmi előfeltételének, hanem a olyan ballasztnak tekinti, amelyet a gazdaság teljesítményét fékezi. ${ }^{9}$ Az ILO-tanulmánykötetet arra mutat rá, hogy a rövid távú, a költ-

9 Ennek a gondolatkörnek az egyik tipikus megfogalmazása volt a magyar diskurzusban a „koraszülött jóléti állam” elképzelése, amelynek a gyakorlatban megvalósult következményei különösen jól láthatóak voltak Magyarország gyenge alkalmazkodóképességében a világgazdasági válságtól a jelenig tartó időszakban. 
séghatékonyság szempontjait mechanikusan alkalmazó fejlesztéssel (low road of development) szemben létezik egy másik út, amelynek kimunkálása jelentős időráfordításokkal járó párbeszédet igényel a különböző társadalmi partnerekkel, viszont jobban alkalmazkodik a helyi viszonyok sajátosságaihoz, és amely a válságból való kilábalást egy felfelé futó spirál elindításában képzeli el (high road of development). A válság hatása éppen abban mutatkozik meg, hogy az európai országok által képviselt különböző intézményi modellek eltérő hatékonysággal tudtak szembenézni a válság jelentette kihivásokkal, és éppen a szociális szempontokra és a helyi sajátosságokra egyaránt tekintettel levő, a társadalmi párbeszéd intézményeire támaszkodó országok bizonyultak sikeresnek, szemben a periféria országaival.

\section{KIHÍVÁSOK A MAGYAR TÁRSADALOMTUDOMÁNY SZÁMÁRA}

A magyar társadalom az elmúlt 25 évben változó intenzitású integrációs és dezintegrációs mechanizmusokon ment keresztül. A kilencvenes évek elején a társadalmi integráció korábban múködő intézményei viharos gyorsasággal bomlottak le vagy alakultak át. A társadalmi kohéziót megteremtő olyan alrendszerek mentek át a társadalmi változások szempontjából roppant rövid idő alatt radikális átalakuláson, mint az oktatás, a szociálpolitika, az egészségügy, a foglalkoztatás, vagy akár a politika, a közbiztonság és a tömegkommunikáció intézményei. Talán nem túlzás azt állítani, hogy a magyar társadalom ezekben az években anomikus sokkon ment keresztül: a régi rendszer intézményeinek integratív ereje megkopott vagy teljesen elhalt, az újak pedig még nem látszódtak kialakulni.

Ezzel párhuzamosan a nemzetközi színtéren jelentős integrációs mechanizmusok indultak be az Európai Unió intézményrendszereinek egyre szorosabbá válásával, az európai politikai integrációs mechanizmusok felgyorsulásával. Ez annál is inkább fontos mozzanat volt a magyar társadalom átalakulásában, mivel az európai orientáció és az Unióhoz történő csatlakozás szükségessége egyike volt azon igen kevés normának, amelyek tekintetében, még ha más és más okból is, de lényegében közmegegyezés alakult ki. A korábban bemutatottaknak megfelelően heterogén, a magyar politikai diskurzusban mégis homogén módon megjelenő „Európa” lett (újra) a mintának tekintett fejlődési irány, amelynek értékeit, normáit, politikai és társadalmi berendezkedését a hazai viszonyok sajátosságainak megfelelően adaptálva, nem csak a politikai elit, de talán a társadalom többsége is elérhetőnek tartotta az átmenetet a szocializmusból az új társadalmi rend felé.

Mindezekből következően kulcsfontosságú kérdés a tanulmányban vázolt rendszerek és a köztük fennálló viszonyrendszer átalakulásának vizsgálata. 25 év után legitim szociológiai kérdés, hogy a magyar társadalom intézményei milyen mechanizmusokon keresztül és milyen mértékben termelik újjá a társadalmi egyenlőtlenségeket, mennyire követik az európai mintákat, melyek - mint azt már korábban illusztráltuk - maguk is igen sokfélék.

Különösen időszerú kérdések ezek manapság, amikor a legújabb európai agenda egyik kiemelt célja az úgynevezett inkluzív vagy befogadó növekedés megteremtése, amely a társadalom eddigieknél szélesebb rétegei számára kínálja felzárkózás lehetőségét. Nem más tehát a cél Európában sem, mint a társadalmi integráció növelése, a gazdasági, társadalmi és területi kohézió szintjének emelése. Mindezeket elsősorban a képzés, a foglalkoztatás és a szociálpolitika eszközrendszerén keresztül kívánja elérni az EU, amely jelentős problémákkal 
volt kénytelen szembesülni. Már a válság előtt is jelentős problémát okozott az idősödő népesség, a foglalkoztatás alacsony szintje, a jelentős mértékű munkanélküliség a fiatalok körében. Az európai munkavállalók 8\%-a dolgozó szegény, vagyis van munkája, de nem keres eleget ahhoz, hogy a szegénységi küszöb fölé kerüljön, csaknem 80 millió ember kizárólag alacsony vagy alapvégzettséggel rendelkezik, és ugyanennyire tehető azok száma, akiket a szegénység közvetlenül veszélyeztet. ${ }^{10}$

Magyarországon a fenti mutatók többségében az európai átlagnál kedvezőtlenebb tendencia érvényesül, a problémáink tehát közösek az EU más tagállamaival. Ahhoz, hogy legyen esélyünk megoldani az integrációval kapcsolatos problémákat, nélkülözhetetlen mélyebben megismerni azokat az összefüggéseket, amelyek például a társadalmi hatékonyság növelését és a méltányosság szempontjainak érvényesülését szolgáló intézmények között fennállnak. Egy, az intézmények és a társadalmi integráció kapcsolatát vizsgáló empirikus program természetesen nem vállalkozhat e komplex kérdéskör minden dimenziójának vizsgálatára, ugyanakkor néhány kiválasztott intézmény múködési mechanizmusainak feltárása révén jól azonosíthatóvá válnak azok a sajátosságok, amelyek a magyar intézmények társadalmi integrációban betöltött szerepét jellemzik.

A tanulmányban bemutatott tipizálási kísérletek elsősorban a forrásokhoz való hozzáférés, a szociális védelem, a szegénység és társadalmi kirekesztődés ellen alkalmazott eszközök alapján igyekeztek bemutatni azokat az intézményi kereteket, amelyek közvetlenül összekapcsolódnak a társadalmi integráció problémájával. Az integráció módját és mértékét azonban nem csak a szociális transzferek befolyásolják, hanem a munkaerőpiac múködése, a társadalom értékrendje, az elit és egyéb társadalmi csoportok egymáshoz való viszonya és konfliktusai, a rendelkezésre álló erőforrások mennyisége és minősége, stb. Ezen tényezők egy része empirikusan viszonylag jól, más része nehezebben megragadható, ami nyilvánvalóan behatárolja a kutatók mozgásterét, ráadásul együttes vizsgálatuk annyira erőforrás-igényes, hogy egyetlen kutatási programban való elemzésük irreális célkitűzés lenne.

Ennek megfelelően a jelen tanulmányon alapuló empirikus kutatás fóként a magyar társadalom integrációs folyamatai mögött meghúzódó intézményi logikák és gyakorlatok tanulmányozása vonatkozhat. A számos vizsgálható és vizsgálandó intézmény közül két tényezőt érdemes kiemelni. Az egyik a javak elosztásának, illetve újraelosztásának (redisztribúciójának) kitüntetett szerepe a társadalmi integrációban. A kutatás során azon intézmények múködéséről volna célszerú mélyebb képet alkotni, amelyek valamilyen módon befolyásolják a források elosztásának logikáját, illetve gyakorlatát, legyen azok pénzbeli transzferek vagy olyan szimbolikus erőforrások, mint például a szaktudás. Az elemzésben külön hangsúlyt érdemes fektetni a munkaerő-piaci részvétel esélyeit befolyásoló intézmények múködésének megértésére, és a kutatást az integrációs tényezők mellett azokra a folyamatokra is ki lehet terjeszteni, amelyek kifejezetten abba az irányba hatnak, hogy különböző társadalmi csoportokat korlátozzanak, vagy más csoportokat privilegizáljanak a forrásokhoz való hozzáférésben. A források elosztásának logikája mellett - mintegy az érem másik oldalként -, hangsúlyosan érdemes foglalkozni a jóléti (oktatási, egészségügyi, szociális) szolgáltatások színvonalának és a hozzájuk való hozzáférés esélyeiben mutatkozó egyenlőtlenségek problematikájával is, amely szolgáltatások maguk is nagyban hozzájárulnak a befogadó társadalmi növekedés erőforrásainak megteremtéséhez, illetve fenntartásához.

10 Forrás: http://ec.europa.eu/europe2020/europe-2020-in-a-nutshell/priorities/inclusive-growth/index_hu.htm 
A téma tehát szerteágazó kutatási perspektivákat kínál, amelyek együttesen és külön-külön is alkalmasak lehetnek arra, hogy mélyebben megértsük a régióban zajló integrációs és dezintegrációs folyamatokat, általánosabban pedig arra, hogy magyarázatot adjunk a térség és benne Magyarország modernizációs folyamatainak sikereire és kudarcaira. 


\section{HIVATKOZÁSOK}

Albert, M. (1991) Capitalisme contre capitalism. Paris: Le Seuil. http://dx.doi.org/10.7202/703143ar.

Amable, B. (2005) The Diversity of Socio-Economic Models. Actes du GERPISE Research International, Á l'Est du nouveau? Eastern Europe: What's New? No. 39, 7-31. http://dx.doi.org/10.1093/019926113x.003.0005.

Beblavý, M. (2008) New welfare state models based on the new member states' experience? Bratislava: Slovak Governance Institute, Faculty of Social and Economic Sciences, Comenius University. http://dx.doi.org/10.2139/ssrn.2403764.

Berlou, J. Ph. - Carrincazeux, Ch. (2005) La Diveresité des Capitalisms et des Pays de L'Europe Centrale et Orientale. Actes du GERPISE Research International, Á l’Est du nouveau? Eastern Eruope: What's New? No. 39, 33-82.

Boeri, T. (2002) Let Social Models Compete and Europe Will Win. Paper presented at a Conference hosted by the Kennedy School of Government, Harvard University, 11-12 April.

Bohle, D. - Greskovits, B. (2012) Capitalist diversity on Europe's periphery. Ithaca: Cornell University Press.

Bourdieu, P. (1990) The Logic of Practice, Stanford: Stanford University Press.

Boyer, R. - Freyssenet, M. (1996) Des Models Industriels Aux Strategies D'Internationalisation, Paris: CEPREMAP, CNRS, E.H.E.S.S. CNRS, GERPISA, University Evry, June, 90.

Boyer, R. (1990) The Regulation School: A Critical Introduction. New York: Columbia University Press.

Cameron, D. R. (1978) The Expansion of the Public Economy: A Comparative Analysis. American Political Science Review 72:1243-61. http://dx.doi.org/10.2307/1954537.

Composto, R. (2008) Welfare State Models in the Enlarged European Union: A Cluster Analysis. Criss Working Paper. No. 27.

Cook, L. J. (2007) Postcommunist welfare states: reform politics in Russia and Eastern Europe. Ithaca: Cornell University Press.

Esping-Andersen, G. (1990) The Three Worlds of Welfare Capitalism, London: Polity Press.

Farkas, É. - Makó, Cs. - Illéssy, M. - Csizmadia, P. (2012) A magyar gazdaság integrációja és a szegmentált kapitalizmus elmélete. In Kovách, I. - Dupcsik, Cs. - P. Tóth, T. - Takács, J. (szerk.) Társadalmi integráció a jelenkori Magyarországon. Budapest: MTA TK SZI.

Gallie, D. (2007) Production regimes, employment regimes and the quality of work. In Gallie, D. (ed.) Employment Regimes and the Quality of Work. New York: Oxford University Press, 1-33. http://dx.doi.org/10.1093/acprof:oso/9780199230105.001.0001.

Gallie, D. (2013) Economic Crisis, Quality of Work and Social Integration: Topline Results from Rounds 2 and 5 of the European Social Survey, London: Centre for Comparative Social Surveys. http://dx.doi.org/10.1093/acprof:oso/9780199664719.001.0001.

Giddens, A. (1984) The Constitution of Society, Berkeley: University of California Press. http://dx.doi.org/10.1093/acprof:oso/9780199664719.001.0001.

Greskovits, B. (2010) Evolving Patterns of Democratic Capitalism in Central-Eastern Europe. Habilitation Theses. University of Debrecen, Faculty of Economics and Business Administration.

Hage, G. (2000) Path dependencies of education systems and the division of labour within organizations: Formalizing the societal effects perspective. In Maurice, M. - Sorge, A. (eds.) Embedding Organizations: Societal Analysis of Actors, Organizations. Amsterdam/Philadelphia: John Benjamins Publishing Co. http://dx.doi.org/10.1075/aios.4.27hag.

Hall, P. (1986) Governing the Economy: The Politics of State Intervention in Britain and France. Cambridge: Polity Press.

Hall, P. - Soskice, D. (eds.) (2001) Varieties of Capitalism. The Institutional Foundations of Comparative Advantage. Oxford: Oxford University Press. http://dx.doi.org/10.1093/0199247757.001.0001.

Katzenstein, P. (1985) Small States in World Markets: Industrial Policy in Europe. Ithaca, N.Y.: Cornell University Press. http://dx.doi.org/10.2307/1960594.

Lane, D. (2006) The Development of Capitalism in Central and Eastern Europe. Paisley: University of Paisly-Paisly Conference Paper, 31. http://dx.doi.org/10.7135/upo9780857286536.002.

Lindbeck, A. (1975) Business Cycles, Politics, and International Economic Dependence. Skandinaviska Enskilden Bank Quarterly Review, 2:53-68.

Lundvall, B-A. (2004) Why the New Economy is a Learning Economy? DRUID Working Paper, No. 04-01.

Makó, Cs. - Csizmadia, P. - Illéssy, M. (2013) Mapping of the Context of Tertiary Lifelong Learning, Barcelona: Dia-e-Logos. http://dx.doi.org/10.7135/upo9781843318224.015.

Martin, R. (2008) Post-socialist segmented capitalism: The case of Hungary. Developing business systems theory. Human Relations, 61(11): 131-159. http://dx.doi.org/10.1177/0018726707085948. 
Nielsen, P. (2006) The Human Side of Innovation Systems: Innovation, New Organization Forms and Competence Building in a Learning Perspective. Aalborg: Aalborg Universiteitsforlag.

North, D. C. (1990) Institutions, Institutional Change and Economic Performance. Cambridge: Cambridge University Press. http://dx.doi.org/10.1017/cbo9780511808678.

Orenstein, M.A. (2008) Postcommunist welfare states. Journal of Democracy. Volume 19, Number 4, October, 80-94. http://dx.doi.org/10.1353/jod.0.0038.

Sapir, A. (2005) Globalization and Reform of European Social Models. Paper presented at the ECOFIN informal meeting of EU Finance Ministers and Central Bank Governors, Manchester, 9th September 2005.

Schonfield, A. (1969) Modern Capitalism: The Changing Balance of Public and Private Power. London: Royal Institute of International Affairs.

Soskice, D. (2000) Explaining changes in institutional frameworks: Societal patterns of business coordination. In Maurice, M. - Sorge, A. (eds.) Embedding Organizations: Societal Analysis of Actors, Organizations. Amsterdam/Philadelphia: John Benjamins Publishing Co. http://dx.doi.org/10.1075/aios.4.15sos.

Soskice, D. - Hall, P. (eds.) (2001) Varieties of Capitalism. The Institutional Foundations of Comparative Advantage. Oxford: Oxford University Press. http://dx.doi.org/10.1093/0199247757.001.0001.

Szelényi, I. - Wilk, K. (2010) Institutional transformation in European post-communist regimes. In Morgan, G. - Campbell, J. L. Crouch, C. - Pedersen, O. K. - Whitley, R. (eds.) The Oxford Handbook of Comparative Institutional Analysis. Oxford: Oxford University Press. http://dx.doi.org/10.1093/oxfordhb/9780199233762.003.0020.

Thelen, K. - Steinmo, S. (1992) Historical institutionalism in comparative politics. In Steinmo, S. - Thelen, K. - Longstreth, F. (eds.) Structuring Politics: Historical Institutionalism in Comparative Analysis. Cambridge: Cambridge University Press. http://dx.doi.org/10.1017/cbo9780511528125.002.

Titmuss, R.M. (1958) Essays on the Welfare State. London: Allen and Unwin.

Vatn, A. (2005) Rationality, Institutions and Environmental Policy. Ecological Economics, 55(2):203-217. http://dx.doi.org/10.1016/j.ecolecon.2004.12.001.

Vaughan-Whitehead, D. (2015) Introduction. In Vaughan-Whitehead, D. (ed.) Is Europe Losing Its Soul? The European Social Model in Times of Crisis. Cheltenham: Edward Edgar/Geneva: ILO. http://dx.doi.org/10.4337/9781783476565.

Whitley, R. (1999) Divergent Capitalisms: The Social Structuring and Change of Business Systems. Oxford: Oxford Uniersity Press.

Zysman, J. (1983) Governments, Markets, and Growth: Financial Systems and Politics of Industrial Change. Ithaca: Cornell University Press. 